\title{
Impacts of Accountability, Integrity, and Internal Control on Organizational Value Creation: Evidence from Malaysian Government Linked Companies
}

\author{
Jamaliah Said \\ Accounting Research Institute \\ Universiti Teknologi MARA, Shah Alam, Malaysia \\ Email: jamaliah533@salam.uitm.edu.my \\ Md. Mahmudul Alam * \\ School of Economics, Finance \& Banking \\ Universiti Utara Malaysia, Sintok, Malaysia \\ E-mail: rony000@gmail.com \\ Nurazwani Mat Radzi \\ Department of Accountancy \\ Faculty of Accountancy and Managemen \\ Universiti Tunku Abdul Rahman, Selangor, Malaysia \\ Email: nurazwani@utar.edu.my \\ Mohamad Hafiz Rosli \\ Faculty of Business and Accountancy \\ Universiti Selangor, Shah Alam, Malaysia \\ Email: mohd_hafiz@unisel.edu.my \\ * Corresponding author
}

\section{Citation Reference:}

Said, J., Alam, M.M., Radzi, N.M. \& Rosli, M.H. (2020). Impacts of Accountability, Integrity, and Internal Control on Organizational Value Creation: Evidence from Malaysian Government Linked Companies. International Journal of Business Governance and Ethics, 14(2), 206 - 223. (online) https://dx.doi.org/10.1504/IJBGE.2020.106350

This is a pre-publication copy.

The published article is copyrighted by the publisher of the journal. 


\title{
Impacts of Accountability, Integrity, and Internal Control on Organizational Value Creation: Evidence from Malaysian Government Linked Companies
}

\begin{abstract}
Credible and well-functioning governance is crucial for the value creation of firms. Recently, private sectors have undergone substantial changes by focusing on good governance as a tool to enhance value, reputation, and image. The primary features of firms with good governance include greater emphasis on accountability practices, proper implementation of a corporate integrity system, and sound internal controls in place to avoid risk and to ensure policy and procedures that are complied. Government Linked Companies (GLCs) as the backbone of the Malaysian government have been harshly criticised for not being able to create value(s) despite receiving high priority in the process of getting government projects. Therefore, this study aims to examine the role of good governance systems, which are reflected through accountability systems, corporate integrity systems, and internal control systems towards value creation of Malaysian GLCs. This study collected primary data based on a set of questionnaire survey among 100 GLCs in Malaysia. Based on the regression analysis, this study found that corporate integrity systems and internal control systems were vital elements in ensuring value creation in GLCs.
\end{abstract}

Keywords: value creation; accountability; integrity systems; internal control; government linked companies; Malaysia

\section{Introduction}

Government Linked Companies (GLCs) are known as companies that have a primary commercial objective, and under the purview of the objective, the Malaysian Government has a direct controlling stake, which refers to the Government's ability to appoint Board of Director (BOD) members, senior management, and the governmental body is involved in making major decisions for GLCs. Furthermore, the uniqueness of GLCs attributes is their exceptional preferences as far as their access to finances, tenders, and opportunities is concerned; the uniqueness that scarcely fits into a privately owned business and the administration has held significant shareholding in these organizations (Abd Rahman et al., 2011). It is reported that GLCs contribute to $54 \%$ of the shares in Kuala Lumpur Composite Index (KLCI) and employ 5\% of the total of national workforce (Putrajaya Committee, 2015). Consequently, having perceived these conditions of GLCs and their essential parts in the nation's monetary development, they are required to share the administration obligation in releasing their open responsibility by driving others to have best corporate practices on social and natural matters as well as value creation (Abd Rahman et al., 2011).

In Malaysia, the key drivers of government revenue are obtained from GLCs (Putrajaya Committee, 2010). When GLCs is considered as the key driver of government income, it becomes vital for GLCs to maintain their value towards the improvement of the Malaysian economy, and this objective is in parallel with the government's goals (Said et al., 2016, 2017). In order for GLCs to maintain their sustainable competitive performance, they have to focus on value creation. This was stated by the Prime Minister during the launch of the new Transformation Programme (Putrajaya Committee, 2010). However, with the lack of focus on value creation, most of the GLCs in Malaysia have reportedly underperformed (Lau \& Tong, 2008). This affects the Malaysian government's economy in achieving Vision 2020. In addition, the fall of huge key players in the GLCs has affected the value creation of the GLCs 
from the public's point of view in addition with the loss of confidence among their potential and existing investors.

Value creation begins strategizing a business plan, investigating and identifying the opportunities for development, implementing appropriate changes or assuring new development for optimal success, and analysing the overall steps so that the management will stay abreast with new changes, internally and externally (Fuller, 2001). Recently, stakeholders have switched from focusing on firms' performance to firms' value creation to ensure sustainability (Lorne \& Dilling, 2012). According to Moran et al. (1997), value creation by firms can be achieved by continuously nurturing good relations with the stakeholders, focusing on the wealth management of stakeholders, and managerial competencies that lead to the development of a sustainable business (Edvardsson \& Oskarsson, 2011; Bowman \& Ambrosini, 2010). Hence, value creation is a very crucial element in GLCs with regard to surviving and sustaining the business in the global market. Thus, value creation could be generated by ensuring good governance practices through accountability, integrity, and good internal control.

Recent financial crisis has also drawn attention from the public about the weaknesses of corporate governance practices among the GLCs (Said, Alam \& Zulkarnain, 2016; Maizatul, Alam \& Said, 2016). Some studies have argued that firms with close links to the government are always excluded from legal corporate actions (Zainal Abidin \& Ahmad, 2007). Failure to practice good governance affects the process of value creation (Norwani, Mohamad, \& Chek, 2011). Similarly, Thomsen (2005) found that good governance structures influenced firms' value. The Malaysian Code of Corporate Governance 2012 has established several mechanisms that relate accountability, integrity, and internal control mechanism aimed at further enhancing the domestic and global values of the Malaysian market. However, there are limited studies that are related to the impact of accountability, integrity, and internal control towards value creation among GLCs.

Therefore, this paper aims to investigate the influence of accountability, integrity, and internal control on value creation among the Malaysian GLCs. This paper is structured as follows: firstly introduction, secondly, discussion on the literature review and hypotheses development, which is followed by third part, i.e. explanation on methodology, and fourthly, discussion of the findings. Finally, the conclusions and implications of the present study are given.

\section{Literature Review and Hypotheses Development}

\subsection{Agency Theory}

This study applied Agency Theory as underpinning theory that was used to develop the hypotheses and the research framework. According to Jensen and Meckling (1976), the relationship between shareholders and managers provides a comprehensive overview of agency relationships. This agency correlation relates the segregation of ownership and control within the company structure. Jensen and Meckling describe the correlation as characterising the modern corporation and encompassing the ways managers and shareholders might act to control these costs to maximise firm value.

Denis (2001) stated that there were two conditions to have an effective governance mechanism. Firstly, the mechanism should serve to narrow the gap between managers' and 
shareholders' interests Secondly, the mechanism should have a significant impact on corporate performance and value. Also, Denis added that when firms were all in equilibrium with respect to their governance mechanisms, no meaningful relationship between any individual mechanism and performance would be observed. Thus, this is where the influence of accountability, integrity, and internal control is needed in order to create a good corporate governance practices that enhance the firm's value.

\subsection{Corporate Governance, Government Linked Companies and Value Creation}

In Malaysia, all the public listed companies are obliged to produce the financial reporting on the corporate governance matters based on the Revised Listing Requirements of Bursa Malaysia in 2001. Under this requirement, the companies have to clarify the disclosures of the code of conduct whether they follow or practise the conduct or not. Thus, Bursa Malaysia also drew the guidelines on the code of conducts that should be implemented by the companies (Securities Commission Malaysia (2017). In fact, the Malaysian Code of Corporate Governance 2012 has highlighted the importance of accountability, integrity, and internal control in every organization to improve its market values.

Therefore, based on the good practice of code of corporate governance, it is seen that the practice will have impacts on corporate values in GLCs. According to the study conducted by Thomsen (2004), the three governance mechanisms that were tested in the study were ownership structure, board composition and stakeholder influence that might have an impact on corporate values. Based on their study, it can be said that the corporate values may differ across the companies as the changes of corporate values starts from the corporate ownership, which is related to the identity and the bargaining power of the influential stakeholders. In addition, the above mentioned study also stated that the board compositions, i.e. the background, personalities or its demographics might install new values of the organization.

Past studies have shown that there is a relationship between governance, corporate social responsibility (CSR) and value creation. For example, Gholami (2011) discovered that CSR created value within organization and society. Thus, CSR is one of mechanisms with regard to accountability in the business and competitive market. The elements in CSR, such as resource and process, strategy, stakeholder and business propositions would generate value creation for corporations and society as well as enhance its accountability.

Moreover, some studies have highlighted the connection between corporate governance (CG) and value creation, and the studies include the research work of Castaner and Kavadis (2013), Charreaux and Desbrières (2001) and Huse (2007). For instance, Charreaux and Desbrières (2001) stated that the analysis of the value creation process was related to the CG system and was not limited to the relationship with shareholders and its control over managers. A study by Castaner \& Kavadis (2013) proposed a comprehensive framework, which encompassed the impact of corporate governance on financial diversification. Their findings showed that financial diversification negatively affected shareholder return and firm value. Another study by Huse (2007) mentioned the existence of relationship between BOD and value creation. Therefore, it is observed that there is a significant influence of governance and CSR in generating value creation. However, most of the studies conducted from the point of view of developed countries leave a room for further study in the context of developing countries.

Past studies have examined the effect of accountability, integrity, and internal control on the firm's performance and the effectiveness of the financial reporting However, limited numbers 
of studies have examined the accountability, integrity, and internal control in the perspective of Malaysian GLCs, and an investigation in that line could benefit the management by generating value creation. Besides, these mechanisms could be served as a reference to GLCs as it would guide them by creating and implementing good governance practice, which can be applied in their organization.

\subsection{Accountability and Value Creation}

Several scholars have studied the relation between accountability and value creation, and they are Beckett and Jonker (2002), Brennan and Solomon (2008), Goddard and Powell (1994), Gray, Owen and Adams (1996) and Kloot (1999). For instance, Gray et al (1996) described that the accountability could be defined as 'the duty to provide an account or reckoning of those actions for which one is held responsible'. They also suggested that the essential elements in the accountability were the relationship between the shareholders and managers and the right information for the shareholders and the duty of the managers to provide the information to the shareholders. Furthermore, the information that should be released by the organizations might be guided based on the demand of the specific stakeholders.

According to Brennan and Solomon (2008), the main concern on corporate governance issues, especially accountability should also focus on the stakeholders, not only shareholder as the previous studies have focused primarily on shareholder. It is the key ingredient that maintains sustainable stakeholder accountability and social responsibility. The authors also emphasized on some areas that should be focus in the study not only at the corporate and country level, but also in the internal area of the organization. On the other hand, Kloot (1999) conducted a study about performance measurement system and accountability and discovered that the greater use of performance measurement might led to a greater imposition of accountability. Thus, the increased awareness on accountability encourages the effective implementation of value measurement. Hence, the accountability of the firm does have influence on the firm values.

A study conducted by Goddard and Powell (1994) found that in order to develop an advanced comprehensive system, a proper accountability system needed to be practised. The accountability system would have policy accountability, programme and performance accountability, and accountability for probity and legality. However, Beckett and Jonker (2002) developed a new standard of accountability to make clarity on the accountability and sustainability that were related and complementary. However, the sustainability for the business should be related to the growth of the business to create value.

Even though major number of studies are conducted relates the accountability with the performance of the organization, there are studies that relates the accountability towards value creation based on the new standard that has been developed to create sustainability of growth for the organization. Most of the scholars have found that accountability has a positive relationship with the sustainability of the business growth, which might have an impact on the firm values. However, there are limited studies that deal with the perspective of developing countries. As such, the current study attempts to investigate the relationship between accountability and value creation in the context of Malaysian GLCs. Therefore, the first hypothesis is proposed as follows:

\section{H1: There is a positive relationship between accountability and firms'value creation.}




\subsection{Corporate Integrity and Value Creation}

According to Rosa (2007), there are three categories of integrity, namely personal, organizational, and moral integrity. Prosser (2012) highlighted the issue of integrity in the context of Australian government. The new integrity issues are related to the independent and minority government, and they affect the value of the government itself. Thus, in order to overcome the new issues of integrity, which are related to the parliamentary of the Australian government, the author developed a model of parliamentary integrity with the aim to expanding the need for political aspects to use this model for practical utility by solving the challenges that were faced. Hence, through this study, it can be found whether the integrity of an organization might have an impact on its value.

However, Head (2012) studied the contribution of integrity agencies towards good governance and the impacts of corporate values. The author discussed the roles of integrity agencies that are specialized when the systems in the country or organizations' accountability and transparency are well incorporated with good political leadership to encourage creation of good value. Pies et al. (2009) stated that the companies' purpose in business is to have a social mandate that will benefit both the organization and the society. Thus, for the companies, to fulfil successfully their social mandate, they have to have good business integrity or business ethics as emphasized in the above mentioned study so that they can be competent in value creation for their organizations.

In relation to the foregoing aspect, Pitelis (2013) stated that in order to have worldwide value creation, an organization had to be 'ethically correct', and this means that the organization has to have good integrity towards the practice of good governance so that good integrity will help contribute towards economic sustainability through the development of value creation. Good corporate governance practices together with good organizational integrity will help create value for the organization, and it will encourage the sustainability of the economy for that organization (Alam, Johari \& Said, 2018).

Thus, the studies that mentioned the importance of integrity in organization, and the integrity that leads to value creation. Some argued that the business ethics should be properly delivered as they will help to promote the creation of value, to evaluate management competencies, and to contribute significantly towards global problem solving. Thus, the business ethics or integrity should be properly addressed to help not only the organizations but also many other 'future social entrepreneurs' to understand what and how value creation occurs through the competencies of the management from the perspective of the organization and also from a global perspective that is beneficial for both the organization and the nation. Hence, the good practices of accountability and transparency in an organization together with a sound system of leadership style will lead to good governance practices, which in turn could create high value for the nation and the organization. Thus, it is maintained that the organization plays a major role in the business path in the long-term. Hence, the second hypothesis has been proposed as follows:

H2: There is a positive relationship between corporate integrity and firms'value creation. 


\subsection{Internal Control and Value Creation}

Internal control is a process designed by "...the company's principal executive and principal financial officers... and affected by the company's board of directors, management, and other personnel, to provide reasonable assurance regarding reliability of financial statement and preparation of financial report for external reporting in accordance with generally accepted accounting principles" (PCAOB Auditing Standard No. 5, 2004). IFAC (2012) defined internal control as the entire organizational system that helps to treat the risk that effectuates the internal control system. However, according to the Committee of Sponsoring Organizations of the Treadway Commission (COSO), the International Auditing and Assurance Standards Board, the internal control can be defined as "the process designed, implemented, and maintained by those charged with governance, management, and other personnel to provide reasonable assurance about the achievement of an entity's objectives with regard to reliability of financial reporting, effectiveness and efficiency of operations, and compliance with applicable laws and regulations."

IFAC (International Federation of Accountant) (2012) highlighted the importance of the internal control system as it is considered as a vital aspect of an organization's governance system and ability to manage risk. In addition, internal control system is fundamental to supporting the achievement of an organization's objectives, enhancing, and protecting stakeholder value. Effective internal control also helps create a competitive advantage since an organization can take additional risks. Hence, internal control system should be regularly monitored and evaluated in order to recognize the part of the system that needs improvement and to limit the risk that might be affected by the ineffectiveness of the system. This internal control (IC) system can be evaluated by the BOD that has to understand its roles and responsibilities in reviewing the policies, taking action against the non-compliance items, and making a better decision. Therefore, the overall policies and procedures of the internal control system of the company can be clearly communicated and disseminated to the entire organization (IFAC, 2012).

A proper framework of business process has been developed, and that is applied in the internal control of the business, which emphasizes on the BOD roles of evaluating the path that helps to create business value for the overall organization. Thus, the business value concept helps enhance the creation of value for the entire business, which gives the BOD insight in creating value and ensuring the sustainable success of the business. Therefore, the effectiveness of the IC process might have an impact on the value creation of the business.

Su et al. (2014) investigated the effects of internal control weaknesses on the responses of the customers, and the effects indicated the firm value. The study of Su et al. (2014) took place after the correspondents of the US corporations encountered failures when the SarbanesOxley (SOX) act was enacted by the U.S Congress in 2002. The researchers examined the determinants that might affect the responses of the customers towards the internal control weaknesses. However, several factors were taken into consideration, and they were the customers' response towards the sales growth, the level of internal controls' weaknesses, types of customers, and good industries. The findings revealed that customers considered the internal control weaknesses before making decisions to buy the products. 
Furthermore, in China, a study was conducted, relating corporate governance and firm value by using the GLCs. The authors stated that the internal control management might have some impact on the firm value. However, the board composition and internal control management might have some impact accompanied with the firm value depending on the shareholders' incentives and the benefits of the stakeholders (Leung \& Cheng, 2013).

In contrast, Connelly et al. (2012) stated in the context of Thailand that the relationship of the corporate governance practice appeared to be positive when the study looked into the good practice of corporate governance $(\mathrm{CG})$ as a whole but not when that study looked particularly at the selected mechanisms of corporate governance towards firm value creation. The study specifically looked into the mechanism of ownership structures, internal control, board independence, and board size and stated that it was hard for the researchers to measure the mechanisms of CG since Thailand had unique conditions of economy, which had different institutional practices compared to other countries. The authors also stated that the effectiveness of good governance practice in Thailand might be blunt, but the governance was well implemented. Hence, based on this study, it can be said that the internal control effectiveness of a firm has two possibilities, which might be either a positive or a negative relationship towards the value creation of the firm.

Thibodeau (2006) in his study demonstrated and related the effect of the format of the audit report and the experience of the auditors towards the evaluation of the internal control in an organization. Most of the auditors who completed an Internal Control Questionnaire (ICQ) correctly identified more internal control design weaknesses than auditors who prepared a narrative. Internal control evaluation experience moderated the effect of the format of the audit report. The results implied that the questionnaire documentation format stimulated an auditor's existing internal control knowledge; as a result, the knowledge enhanced performance at the time of identifying internal control design weaknesses. Therefore, the weaknesses of the internal control do affect the firm value.

On the other hand, another study on strategy, control activities, monitoring, and effectiveness was conducted by Agbejule and Jokipii (2009). Their study examined the strategy on control activities, monitoring the control activities, and the level of effectiveness of the internal control systems in the firms from the point of view of the analysts and practitioners in connection with the value of the business. The study found that the views from the practitioners in the firm were that high degrees of internal control activity and low degrees of monitoring would ensure a greater effectiveness of the internal control system. However, based on the view of the analysts, a high degree of internal control activity and high degrees of monitoring would lead to a highly effective internal control system.

However, based on the study regarding the value creation of an internationalizing entrepreneurial firm, Saarenketo et al. (2011) found that although the business models of firms with comparable positions might appear to be similar, there were fine-grained differences both in their activities and in their value formation. Some of the past studies have indicated mix findings on the significant differences between practitioners and analysts' views that relate to the internal control effectiveness towards the business value. Therefore, there is a space of further studies, which need to be investigated. Hence, the third hypothesis has been proposed as follows:

\section{H3: There is a positive relationship between internal control and firms'value} creation. 


\section{Methodology}

\subsection{Sampling and Data Collection}

The data for this study was collected based on a targeted questionnaire survey among the 406 state and federal level GLCs. Out of the targeted 406 samples, total 100 respondents replied the email questionnaires. Therefore, the rate of response is $24.6 \%$. Previous studies also found that the rate of responses was 5-10\% (Alreck \& Settle, 1995). The considered respondents for the questionnaires were accountants or equivalent as they had good experience with internal control systems, accountability systems, and integrity systems in their organizations. The list of GLCs was obtained from the Putrajaya Committee on GLCs (PCG) website $^{1}$ as of July 31, 2014. The questionnaire used a seven-point Likert scale, ranging from 1 (strongly disagree) to 7 (strongly agree).

\subsection{Measurement of Variables}

\subsubsection{Accountability}

This study used ten parameters to measure accountability practices. The variables of the study were adapted with some modification from Collier (2008). The parameters that were considered for the present study were regular reporting system, manner in which income was generated and used, quality and quantity of information shared, board member involvement in strategic planning, decision making, and strategic planning.

\subsubsection{Internal Control}

This study used ten parameters to measure internal control effectiveness that were adapted with some modification from CPA Australia (2005). The items that were asked included board involvement in the establishment of internal control procedure, the adequacy of internal control that was periodically assessed and improved, policy and procedures were informed to stakeholders, ensuring all policy and procedures were complied, monitoring systems in the organization to determine compliance with internal controls, and action taken against non-compliance.

\subsubsection{Integrity}

This study used ten parameters to measure corporate integrity systems, which were adapted with some modifications (Alam, Said \& Aziz, 2019; Said, Alam \& Khalid, 2016). The ten items measured the extent to which the organizations adopted the corporate integrity systems in daily activities which included vision and goals in relation to integrity, the existence of ethics communication, whistle-blowing policy, integrity infrastructure, integrity culture, ethics training and education, disciplinary and rewards measures that covered ethical conduct; confidential advice and support, and measurement, research and assessment.

\subsubsection{Value Creation}

The measurement for value creation was adopted from Wang and Wang (2012). Ten items were asked to measure value creation by including customer satisfaction, quality development, responsiveness, brand value, environment and community issues and reputation, average return on investment, sales growth, profit growth, and average return on

\footnotetext{
${ }^{1}$ Website: www.pcg.gov.my
} 
sales. The respondents were asked to compare all of the value creation measures of their organizations against their competitors in the same industry for at least three years. Detailed parameters for each of the variables are given in the Appendix.

\subsection{Data Analysis}

The data are analysed using descriptive statistics and cross-sectional regression model. Furthermore, the reliability of the data was tested, using the Cronbach's alpha test. Finally, the data validity was tested by checking the normality of data through skewness and kurtosis.

\section{Results and Findings}

\subsection{Demographic Information}

Out of the total respondents, $45 \%$ were from large size companies, $36.7 \%$ were from medium size companies, and $18.3 \%$ respondents were from small size companies. However, in terms of number of employees in the organization, $36.7 \%$ of the organizations had more than 1000 employees, $25 \%$ had 501 to 1000 employees, $21.7 \%$ had 101 to 500 employees. Furthermore, in terms of scope of organizational operation, $40 \%$ were national level organizations, $35 \%$ were local, and $25 \%$ were international.

Out of the total respondents, $65 \%$ were female and $35 \%$ were male. In terms of age of the respondents, $58.3 \%$ of them were below 30 years, $30 \%$ of them were $30-40$ years, and $11.7 \%$ were 41-50 years old. In term of job position, $41.7 \%$ of the respondents were in middle management, $33.3 \%$ were in lower management, $18.3 \%$ were supporting staffs, and $6.7 \%$ were in top management. $61.7 \%$ of the respondents had university degrees, $26.7 \%$ had diplomas, $6.7 \%$ had SPM/MCE/Certificates, and 5\% had professional qualifications. $40 \%$ of the respondents had 1-3 years job experience, $20 \%$ had 5 years job experience, $25 \%$ had more than 5 years job experience, and $15 \%$ had less than 1 year of job experience.

\subsection{Diagnostic Test}

\subsubsection{Normality Test}

Based on the result of the Kolmogorov-Smirnova test, the factors of the factors of accountability, internal control, integrity, and value creation have the value of $p=.200$ (Table 1). The non-significant result (with a significant value of $p>.05$ ) indicates the normality distribution of the scores. Therefore, the data are normally distributed.

Table 1: Test of Normality

\begin{tabular}{ccccccc}
\hline & \multicolumn{2}{c}{ Kolmogorov-Smirnova } & \multicolumn{3}{c}{ Shapiro-Wilk } \\
\hline & Statistic & $\mathrm{df}$ & Sig. & Statistic & $\mathrm{df}$ & Sig. \\
Accountability & 0.101 & 60 & .200 & 0.961 & 60 & 0.051 \\
Internal Control & 0.069 & 60 & .200 & 0.972 & 60 & 0.182 \\
Integrity & 0.088 & 60 & .200 & 0.979 & 60 & 0.402 \\
Value Creation & 0.071 & 60 & .200 & 0.968 & 60 & 0.250 \\
\hline
\end{tabular}

4.2.2 Multicollinearity and Correlation Analysis:

Correlation examines the relationship between two variables in a linear fashion that helps to identify whether one variable is related to another. When two variables are considered highly 
correlated to each other and explain the dependent variable, that relationship will cause a multicollinearity problem if the value of coefficient is 0.8 or 0.9 , and above (Field, 2000). Table 2 shows the summary of the results, and the correlation values among the variables ranged from 0.71 to 0.73 . This finding indicated that there was no multicollinearity problem available among the variables.

Table 2: Pearson Correlation

\begin{tabular}{ccccc}
\hline & Accountability & Internal Control & Integrity & Value Creation \\
\cline { 2 - 5 } Accountability & 1.000 & $.733 * *$ & $.741 * *$ & $.708 * *$ \\
Internal Control & & 1.000 & $.757 * *$ & $.734 * *$ \\
Integrity & & 1.000 & $.761 * *$ \\
Value Creation & & & 1.000 \\
\hline$* *$ indicates correlation is significant at the 0.01 level (two-tailed), and * indicates correlation \\
is significant at the 0.05 level (two-tailed).
\end{tabular}

\subsubsection{Reliability Test}

The Cronbach's Alpha is conducted to measure the correlation between scores for each item in this study. This is also known as the test of the internal consistency approach. The Cronbach's alpha values for accountability, internal control, integrity, and value creation were $0.92,0.83,0.85,0.84$, and they indicate that the reliability of the questions is excellent (George \& Mallery, 2003).

\subsubsection{Factor Analysis}

The Kaiser-Meyer-Olkin coefficient for these datasets was 0.88 for accountability, 0.76 for internal control, 0.84 for integrity, and 0.73 for value creation, and this indicates that the data could be used to proceed with the exploratory factor analysis (Hair et al., 2010). The Principle Component Analysis (PCA) of accountability had an eigenvalue of 6.5; internal control had an eigenvalue of 4.388; integrity had an eigenvalue of 3.94, and value creation had an eigenvalue of 2.805 , which is more than 1 .

\subsection{Regression Analysis}

The regression result shows the goodness fit of the model vis-à-vis $\mathrm{R}^{2}$ was 0.681 (Table 3). Based on the regression result, all of the three variables show significant and positive relationship with value creation. Among the three variables, integrity shows the highest impact and accountability shows the least impact on value creation. This means that the variable of integrity made the strongest unique contribution to explaining value creation. However, the lowest unique contribution towards the dependent variable is accountability. Sound internal control and accountability systems mitigate unethical conduct whereas proper implementation of corporate integrity system promotes managers to act in line with the corporate goals.

Table 3: Regression Output

\begin{tabular}{lcccc}
\hline & Coefficient & Std. Error & t & Sig. \\
\hline Constant & 3.55 & 3.291 & 1.078 & 0.285 \\
Accountability & 0.17 & 0.1 & 1.658 & 0.10 \\
Internal Control & 0.19 & 0.103 & 1.847 & 0.07 \\
Integrity & 0.27 & 0.08 & 3.445 & 0.001 \\
\hline
\end{tabular}




\section{Discussions and Conclusions}

Currently, the issue of value creation has been an emerging issue as the entire stakeholder is knowledgeable about this aspect. Thus, most of the shareholders evaluate the performance of the company based on value creation. However, most of the previous studies have not emphasized on the value creation or the organization but on performances of the organization based on both either financially or non-financially performances. Therefore, this study attempted to focus on the mechanisms of corporate governance, which are accountability, integrity and internal control effectiveness towards the value creation amongst GLCs in Malaysia.

The findings found that all the hypotheses were supported since accountability, integrity and internal control had a significant and positive effect on value creation in GLCs. The hypotheses are consistent with past studies, such as Beckett and Jonker (2002), Kloot (1999), Pies et al. (2009), Pitelis (2013), Jokipii (2009), and Thibodeau (2006).

For instance, Kloot (1999) found that accountability helped improve the performance of the firm, which directly created the firm value. On the other hand, a study conducted by Pies et al. (2009) shows that integrity has positive relationship with firm value creation, which compensates better firm performance. However, the finding by Jokipii (2009) supported that an effectiveness internal control would help the firm to create value as to encourage sustainability of the firm performance.

This study has provided an implication theoretically and practically on the corporate governance and value creation in GLCs. In addition, the good corporate governance practice might give impact on the creation of the firm value. This study has focused on the three of mechanisms for the corporate governance, namely accountability, integrity and internal control effectiveness and its effect on value creation in GLCs. Thus, the findings extend the existing knowledge on corporate governance and value creation, particularly in the context of Malaysian GLCs. In term of practical implication, the findings would assist the management in GLCs to emphasize on the elements of accountability, integrity and internal control effectiveness in order to develop a good corporate governance practice, which leads to value creation. Thus, by having value creation, the organization would achieve its competitive advantage, ensure sustainability, and survival of the business in long-term of period.

Now-a-days, stakeholders are more concerned about sustainable competitive advantage instead of short-term measure of financial performance. As such, value creation, which promises a more sustainable measurement of performance, is seen as crucial for investors with regard to decision-making. This study has found that the features of good governance, including internal control, accountability, and corporate integrity systems, play an important role in creating value for an organization. Thus, a good value creation of an organization can encourage sustainable growth of the organization or business.

This study has to consider some limitations before drawing any conclusion from the findings. The samples are drawn from the GLCs in Malaysia; hence, the findings cannot be generalised to other sector or industries. In addition, cross-sectional research design was applied in this study; thus, longitudinal studies can be conducted to observe the pattern of the findings.

In conclusion, it was shown that the establishment of a corporate integrity system accomplishes the aspiration of the stakeholders by enhancing value creation of Malaysian 
GLCs. As such, it is timely for Malaysian GLCs to place high emphasis on the implementation of corporate integrity systems. Corporate integrity systems provide a platform for managers and organizational members to do their best by complying with rules and procedures. In addition, at the same time they try to maximize shareholders' value. It is also suggested that GLCs implement proper internal control systems and accountability, which provide a vital step in the firms' growth. It also avoids risks and ensures compliance to policies and procedures.

\section{References}

Abd Rahman, N.H.W., Mohamed Zain, M., \& Yahaya Al-Haj, N.H.Y. (2011). CSR disclosures and its determinants: evidence from Malaysian government link companies. Social Responsibility Journal, 7(2), pp. 181-201.

Agbejule, A., \& Jokipii, A. (2009), Strategy, control activities, monitoring and effectiveness. Managerial Auditing Journal, 24(6), 500-522.

Alam, M.M., Johari, R.J. \& Said, J. (2018). An Empirical Assessment of Employee Integrity in the Public Sector of Malaysia, International Journal of Ethics and Systems, 34(4), 458-471.

Alam, M.M., Said, J., \& Aziz, M.A.A. (2019). Role of Integrity System, Internal Control System, and Leadership Practices on the Accountability Practices in the Public Sectors of Malaysia. Social Responsibility Journal, DOI: https://www.emeraldinsight.com/doi/full/10.1108/SRJ-03-2017-0051

Alreck, P. L. \& Settle, R.B. (1995). The survey research handbook, 2nd ed. Chicago: Irwin.

Beckett, R. \& Jonker, J. (2002). Accountability 1000: a new scial standard for building sustainability. Managerial Auditing Journal, 17(1), 36 - 42.

Bowman, C. \& Ambrosini, V. (2010). How value is created,captured and destroyed. European Business Review, 22(5), 479-495.

Brennan, N.M., \&Solomon, J. (2008). Corporate governance, accountability and mechanisms of accountability: an overview. Accounting, Auditing \& Accountability Journal, 21(7), 885-906.

Securities Commission Malaysia (2017) Malaysian Code on Corporate Governance [online] https://www.sc.com.my/api/documentms/download.ashx?id=70a5568b-1937-4d2b$8 \mathrm{cbf}-3$ aefed112c0a (accessed on 26th July 2019)

Castañer, X., \& Kavadis, N. (2013). Does good governance prevent bad strategy? A study of corporate governance, financial diversification, and value creation by French corporations, 2000-2006. Strategic Management Journal, 34(7), 863-876.

Charreaux, G., \& Desbrières, P. (2001). Corporate governance: stakeholder value versus shareholder value. Journal of Management and Governance, 5(2), 107-128.

Collier, P.M., (2008). Stakeholder accountability A field study of the implementation of a governance improvement plan. Accounting, Auditing \& Accountability Journal, 21(7), 933-954.

Connelly, J., Limpaphayom, P. \& Nagarajan, N. (2012). Form versus substance: the effect of ownership structure and corporate governance on firm value in Thailand, Journal of Banking \& Finance, 36 (6), 1722-1743.

CPA Australia. (2005). A Checklist of Internal Controls for Treasury.

Denis, D. K. (2001). Twenty-five years of corporate governance research... and counting. Review of financial economics, 10(3), 191-212.

Edvardsson,I.,R., Oskarsson G.,K. (2011). Knowledge management and value creation in service firms. Measuring Business Excellence, 15(4), 7-15. 
Field, A. (2000). Discovering Statistics using SPSS for Windows, page 2, 44-322, London: Sage Publications.

Fuller, D. N. (2001). Value Creation: Theory and Practice. Value Incorporated. [online] https://www.valueinc.com/press/value-creation-theory-and-practice/ (accessed on 26th July 2019)

George, D., \& Mallery, P. (2003). SPSS for Windows step by step: A simple guide and reference. $4^{\text {th }}$ Edition, Boston: Allyn \& Bacon publisher.

Gholami, S. (2011). Value creation model through corporate social responsibility (CSR). International Journal of Business and Management, 6(9), 148.

Goddard, A., \& Powell, J. (1994). Accountability and Accounting Using Naturalistic Methodology to Enhance Organizational Control - A Case Study. Accounting, Auditing \& Accountability Journal, 7(2), 50-69.

Gray, R.H., Owen, D.L., \& Adams C. (1996). Accounting and accountability: Changes and challenges in corporate social and environmental reporting. London: Prentice Hall.

Hair, J., Black, W., Babin, B., Anderson, R., \& Tatham, R. (2010). Multivariate Data Analysis ( $7^{\text {th }}$ Edition). Uppersaddle River, N.J.: Pearson Prentice Hall.

Head, B.W. (2012). The contribution of integrity agencies to good governance. Policy Studies, 33(1), 7-20.

Huse, M. (2007). Boards, governance and value creation: The human side of corporate governance. Cambridge: Cambridge University Press.

IFAC (International Federation of Accountant). (2012). Evaluating and Improving Internal Control in Organizations

Jensen, M.C. and Meckling, W.H. (1976). Theory of the firm: Managerial behavior, agency costs and ownership structure, Journal of financial economics, 3 (4): 305-360.

Kloot, L. (1999). Performance measurement and accountability in Victorian local government. The International Journal of Public Sector Management, 12(7): 565-584.

Lau,Y.W., \& Tong, C.Q. (2008). Are Malaysian Government-Linked Companies (GLCs) Creating Value? International Applied Economics and Management Letters, 1(1), 912.

Leung, N. W., \& Cheng, M.A. (2013). Corporate governance and firm value: Evidence from Chinese state-controlled listed firms. China Journal of Accounting Research, 6(2), 89112.

Lorne, F.T. \& Dilling, P. (2012). Creating Values for Sustainability: Stakeholders Engagement, Incentive Alignment, and Value Currency. Economic Research International, Article ID 142910. DOI:10.1155/2012/142910

Maizatul, A.K., Alam, M.M., \& Said, J. (2016). Empirical Assessment of the Good Governance in the Public Sectors of Malaysia. Economics \& Sociology, 9(4), 289304.

Moran, P., \& Ghoshal, S. (1997). Value Creation By Firms. Boulevard de Constance, France London Business School, London.

Norwani, N.M., Mohamad, Z.Z. \& Chek. I.T. (2011). Corporate Governance Failure and Its Impact on Financial Reporting Within Selected Companies. International Journal of Business and Social Science, 2(21), 205-213.

PCAOB, Public Company Audit Oversight Board. (2004). Auditing Standard No.5: An Audit of Internal Control Over Financial Reporting That Is Integrated with An Audit Financial Statement.

Pies, I., Hielscher, S., \& Beckmann, M. (2009). Moral commitments and the societal role of business: An ordonomic approach to corporate citizenship. Business Ethics Quarterly, 19(3), 375-401. 
Pitelis, N.C. (2013). Towards a More 'Ethically Correct' Governance for Economic Sustainability. Journal of Business Ethic, 118(3), 655-665.

Prosser, B. (2012). New integrity issues for independents and minority governments. Policy Studies, 33(1): 79-95.

Putrajaya Committee (2010) GLC Transformation Programme Progress Review, Putrajaya Committee on GLC High Performance (PCG) Secretariat, Putrajaya [online] https://www.pcg.gov.my/media/1011/2010.pdf (accessed on 26th July 2019)

Putrajaya Committee (2015) GLC Transformation Programme Graduation Report, Putrajaya Committee on GLC High Performance, Putrajaya [online] https://www.pcg.gov.my/media/1118/glctp-vol1-graduation-report.pdf (accessed on 26th July 2019)

Rosa N.T.R. (2007). Integrity: a systems theory classification. Journal of Management History, 13(1), 74-93.

Said, J., Alam, M.M., \& Khalid, M. (2016). Relationship between Good Governance and Integrity System: Empirical Study on the Public Sector of Malaysia. Humanomics. 32(2), 151-171.

Said, J., Alam, M.M., \& Zulkarnain, N.N. (2016). Entrepreneurial Orientation for Sustainable Competitive Advantage and Risk Management: Evidence from Government-Linked Companies in Malaysia. International Journal of Applied Business and Economic Research, 14(10), 6529-6544.

Said, J., Alam, M.M., Abdullah, N.H.N., Zulkarnain, N.N., \& Anugerah, R. (2016). Innovation Risk and Sustainable Competitive Advantages: Empirical Assessment of Government-Linked Companies in Malaysia. International Journal of Economics and Management, 10(S2), 253- 265.

Said, J., Alam, M.M., Irna, D., \& Rafidi, M. (2017). Does Job Satisfaction, Fair Treatment, and Cooperativeness Influence the Whistleblowing Practice in Malaysian Government Linked Companies? Asia-Pacific Journal of Business Administration, 9(3), 220-231.

Sainio, L., Saarenketo, S., Numemela, N., \& Eriksson, T. (2011). Value creation of an internationalizating entrepreneural firm: The business model perspective. Journal of Small Business and Enterprise Development,18(3),556-570.

Su, L., Zhao, X., \& Zhou, G. (2014). Do customers respond to the disclosure of internal control weakness? Journal of Business Research, 67(7), 1508-1518.

Thibodeau, J.L. (2006). The effect of format and experience on internal control evaluation. Managerial Auditing Journal, 21(9), 877-891.

Thomsen, S. (2004). Corporate Values and Corporate Governance. The International Journal of Business in Society, 4(4), 29 - 46

Thomsen, S. (2005). Corporate governance as a determinant of corporate values. The international journal of business in society, 5(4),10-27.

Wang, Z., \& Wang, N. (2012). Knowledge sharing, innovation and firm performance. Expert Systems with applications, 39(10), 8899-8908.

Zainal Abidin., N.A. \& Ahmad H. (2007). Corporate Governance In Malaysia: The Effect Of Corporate Reforms And State Business Relation In Malaysia. Asian Academy of Management Journal, 12(1) 23-34. 
Appendix: List of the Variables \& Parameters

\begin{tabular}{|c|c|c|}
\hline Variables & Code & Item Description \\
\hline \multirow{9}{*}{ 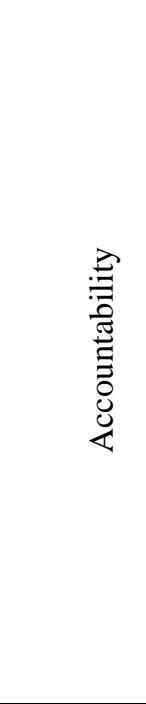 } & B1 & $\begin{array}{l}\text { My organization has a regular reporting system on its achievements towards their goals. } \\
\text { My organization ensures that all funds obtained has been used in the right manner and } \\
\text { properly authorized. }\end{array}$ \\
\hline & B3 & My organization provides the transparent financial and governance information. \\
\hline & B4 & My organization has provided a high standard setting for performance. \\
\hline & B5 & $\begin{array}{l}\text { My organization's board members have actively participated in governing our } \\
\text { organization. }\end{array}$ \\
\hline & B6 & $\begin{array}{l}\text { My organization's board members have received regularly committee report in order to } \\
\text { scrutinize their works. }\end{array}$ \\
\hline & B7 & $\begin{array}{l}\text { My organization has provided education relating on the conflict of interest for all new } \\
\text { board members. }\end{array}$ \\
\hline & B8 & My organization has developed a risk management plan. \\
\hline & B9 & $\begin{array}{l}\text { My organization has clearly defined the roles and responsibilities expected from the } \\
\text { board members. }\end{array}$ \\
\hline & $\mathrm{B} 10$ & $\begin{array}{l}\text { My organization gives attention on complaints and takes a considerable action to } \\
\text { improve their performance. }\end{array}$ \\
\hline \multirow{8}{*}{$\begin{array}{l}\overline{0} \\
\stackrel{\Xi}{0} \\
0 \\
\bar{U} \\
\stackrel{\Xi}{\Xi} \\
\stackrel{\Xi}{\Xi}\end{array}$} & $\mathrm{C} 1$ & $\begin{array}{l}\text { Our board of directors do review the policies and procedures to ensure that appropriate } \\
\text { internal controls have been established. }\end{array}$ \\
\hline & $\mathrm{C} 3$ & $\begin{array}{l}\text { All appropriate and updated information from the organizations relating to accounting } \\
\text { and communication systems have been received by the board for decision making. } \\
\text { Our internal and external auditors are periodically assessing the adequacy of internal } \\
\text { control system. }\end{array}$ \\
\hline & $\mathrm{C} 4$ & The policies and procedures are well informed to all of the staff of my organization. \\
\hline & C5 & All personnel do understand their roles and know how their activities relate to others. \\
\hline & C6 & My organization's accounting system is properly managed and accounted for. \\
\hline & $\mathrm{C} 7$ & $\begin{array}{l}\text { My organization's financial transactions are properly documented and reported in } \\
\text { accordance with the proper accounting standard. }\end{array}$ \\
\hline & C9 & $\begin{array}{l}\text { There is monitoring system in my organization to determine compliance with internal } \\
\text { controls and any instances of non-compliance are reported to the board. } \\
\text { Our board of directors has taken appropriate action in instances of noncompliance that } \\
\text { have been reported. }\end{array}$ \\
\hline & $\mathrm{C} 10$ & Our board of directors' decisions is not controlled by a dominant individual or a group. \\
\hline \multirow{10}{*}{ 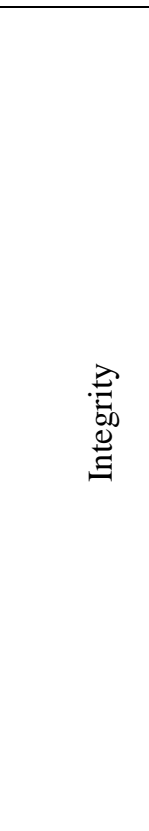 } & D1 & $\begin{array}{l}\text { All of my organization's staff have been clearly informed about the objectives and goals } \\
\text { and understand the connection between ethical value and performances. }\end{array}$ \\
\hline & D2 & $\begin{array}{l}\text { The leaders emphasize the importance of ethical conduct as a core organizational value } \\
\text { and strategy, and providing consistent visible leadership. }\end{array}$ \\
\hline & D3 & $\begin{array}{l}\text { The legal requirements for adopting policies and rules about ethics and integrity have } \\
\text { been complied by my organization. }\end{array}$ \\
\hline & D4 & $\begin{array}{l}\text { All of the policies and rules of the code of conduct for ethics and business are freely } \\
\text { available to all employees. }\end{array}$ \\
\hline & D5 & $\begin{array}{l}\text { My organization has committed itself to ethics and integrity even if there is a } \\
\text { shortcoming. }\end{array}$ \\
\hline & D6 & $\begin{array}{l}\text { My organization can be described as a great place to work, where the trust, ethics, } \\
\text { fairness and integrity are highly valued. }\end{array}$ \\
\hline & D7 & $\begin{array}{l}\text { My organization encourages employees and all anonymous as well as confidential } \\
\text { complaints to speak up and bring forward their concern or complaints about unethical } \\
\text { behaviour or misconduct. }\end{array}$ \\
\hline & D8 & $\begin{array}{l}\text { All of the information and data that had been complained are recorded and summarized } \\
\text { for the management and the board to take further action. }\end{array}$ \\
\hline & D9 & $\begin{array}{l}\text { My organization has been involved in, engaged or supported the communities which the } \\
\text { organization is associated. }\end{array}$ \\
\hline & D10 & My organization does make some effort to involve into social and environment concerns. \\
\hline
\end{tabular}


E1 My organization has produced products that have good quality for our customers.

E2 My organization has produced environment-friendly products for protecting the nature. My organization has taken into consideration economic value added activity and product. Value added activity or product is something that are worth paid by customer and other stakeholders.

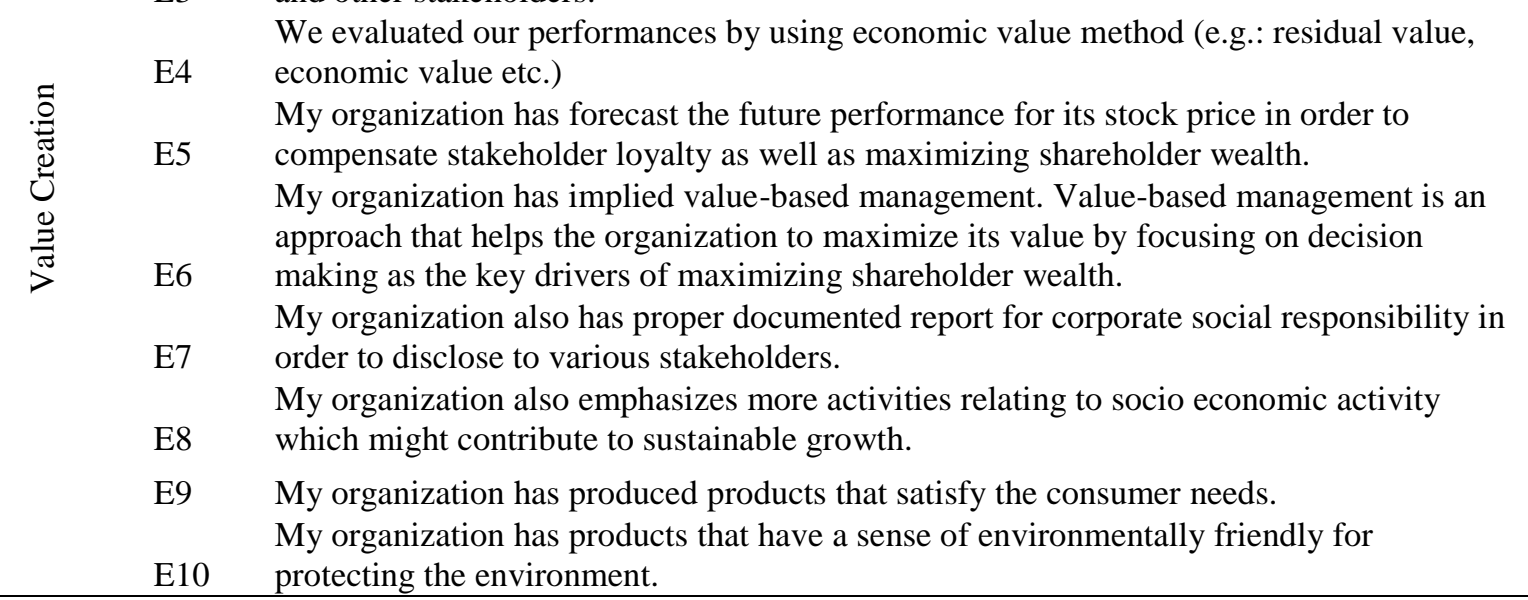

\section{Author's Biography}

Prof. Dr. Jamaliah Said is currently the Deputy Director of Accounting Research Institute, Universiti Teknologi MARA. She has published 100+ journal articles and presented 100+ articles in conferences. She is the managing editor of two eminent journals - Malaysian Accounting Review and Asia Pacific Management Accounting Review. Her main research interests are fraud, governance, accountability, and strategic management.

Dr. Md. Mahmudul Alam is a Senior Lecturer at Universiti Utara Malaysia, and a Research Fellow at Frankfurt School of Finance \& Management, University Technology MARA, and International Islamic University Chittagong. He has more than 100 articles in refereed journals and five books/monographs. He has presented more than 70 articles at international conferences. He is recognized by BDRC as one of the "Top Bangladesh Development Researchers of the Millennium". His research areas include sustainable finance, sustainable development, ecological economics, financial economics and Islamic economics.

Nurazwani Binti Mat Radzi is a Lecturer of Accounting at Universiti Tunku Abdul Rahman. She obtained her Master's degrees in Accountancy from Universiti Teknologi MARA and currently pursuing her Ph.D. in accounting at Universiti Putra Malaysia. Her research areas include management accounting, corporate governance, accountability, integrity, problem-based learning, and sustainability.

Mohamad Hafiz is a Lecturer in Faculty of Business and Accountancy, Universiti Selangor (UNISEL). He holds a Master of Accountancy from Universiti Teknologi MARA (UiTM) Malaysia and Bachelor of Accountancy (Hons) from UNISEL. He is an Associate Member of Malaysian Institute of Accountants (MIA) and Committee Member of Malaysian Accounting Association (MyAA). He has more than ten years of teaching experience. His research interest includes financial accounting and reporting, performance measurement, public sector accounting and behavioral study. He also serves as Associate Captain of Malaysian National Civil Department. 